\title{
Vil «Radiumhospitalet» bestå?
}

\author{
Navnet «Radiumhospitalet» er drøftet i Stortinget tre ganger de siste par årene. Politikerne \\ ønsker at navnet skal bevares. Men det skjer ikke uten sverdslag. Navn er viktig, vanskelig \\ og vekker følelser.
}

Historien startet i 2005 da Radiumhospitalet og Rikshospitalet ble slått sammen til ett sykehus: Rikshospitalet-Radiumhospitalet HF. To år senere ble navnet endret til Rikshospitalet HF. Dermed forsvant Radiumhospitalet som merkenavn fra 1. oktober 2007 (1) - 75 år etter at sykehuset ble etablert (2). Saken kom første gang opp i Stortinget året etter. En enstemmig helse- og omsorgskomité ba statsråden se til at merkenavnet Radiumhospitalet ikke skulle gå tapt (3).

\section{Oslo universitetssykehus}

I 2009 var det tid for nok en nykonstruksjon: Oslo universitetssykehus ble dannet. Igjen ble det sagt at de gamle merkenavnene skulle beholdes: Vi regner med at alle foretakets merkenavn skal videreføres, også innenfor den nye sykehusstrukturen, sa administrerende direktør Morten Reymert (4). Men heller ikke denne gangen skulle det vare.

I januar 2010 sendte stortingsrepresentant Per Arne Olsen (FrP) et brev til helseministeren. Han spurte hva statsråden ville gjøre for å sikre Radiumhospitalet som merkevarenavn både nasjonalt og internasjonalt (5). Statsråden viste til et brev fra Helse Sør-Øst fra 2008 der det sto at merkenavnet Radiumhospitalet ville bli videreført basert på helse- og omsorgskomiteens innstilling. Helse Sør-Øst ville følge med på at navnet Radiumhospitalet ville få den forut-

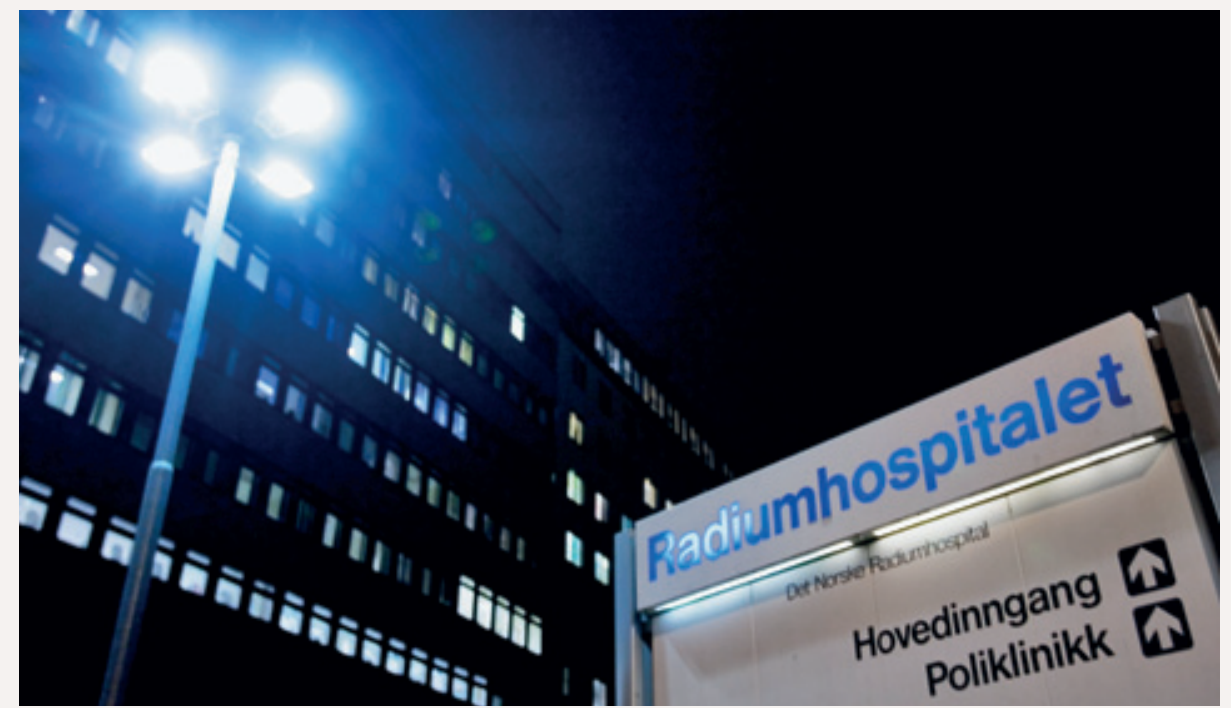
ring».

En måned senere fortalte tidligere kreftpasient Arthur Buchardt til VG at man på brevark og innkallelser til Radiumhospitalet bruker Oslo universitetssykehus, Ullernchausseen, ikke Radiumhospitalet (6).

Saken kom igjen opp i Stortinget. Per Arne Olsen sa at prosessen rundt Oslo universitetssykehus «nok en gang fremtvinger en debatt som jeg trodde var lagt død av helsekomiteen $\mathrm{i}$ forrige periode når man understreket viktigheten av å videreføre Radiumhospitalet som det innarbeidede og anerkjente merkenavnet det er.» Han oppfordret i denne saken en gang til. Meningene var delt. Hva som står på brevark og konvolutter bør ikke være det «som får størst politisk fokus her på Stortinget», sa enkelte (7). Det hjalp lite. Olsen hentet skrekkeksempler fra idretten: Hva ville skjedd hvis Norges Fotballforbund fikk det for seg at Brann skulle skifte navn til Hordaland fotballklubb, avdeling Bergen, sektor Brann - eller at Holmenkollen skiftet navn til Oslo skibakke, avdeling Holmenkollen. Ministeren forsøkte å berolige: «Radiumhospitalet som merkenavn skal bevares,» sa hun (7).

19. april 2010 kom saken opp i Stortinget for tredje gang - igjen på Olsens initiativ. Man tar ikke vare på en merkevare ved å ha navnet nederst, i fjerde linje i en parentes, sa han (8). Statsråden gjentok seg selv. satte «identitets- og profilmessige eksponeministeren «på det sterkeste» til å gripe fatt

\section{Siste kapittel?}

23. juni 2010 skrev VG om saken på nytt. Buchardt hadde igjen uttalt at Radiumhospital-navnet var borte. Helseministeren fastslo nå kategorisk at alle forsøk på fjerne navnet «Radiumhospitalet», ville bli overkjørt. Hun hadde kontaktet Helse Sør-Øst og fått vite at de var innforstått med at navnet Radiumhospitalet skulle bestå. «Helse SørØst forsikret meg om et enhver misforståelse om noe annet, straks skal ryddes opp i,» sa Strøm-Erichsen til avisen (9).

Er siste ord dermed sagt? Merkevarenavnet Radiumhospitalet skal leve videre, alt annet er galskap, uttalte Olsen i kampens hete (6). Navnevalg er sjelden likegyldig $(10,11)$.

\section{Erlend Hem}

erlend.hem@medisin.uio.no

Tidsskriftet

\section{Oppgitte interessekonflikter: Ingen}

\section{Litteratur}

1. Johannessen JV. Illojal og uryddig? VG 25.10.2008: 49.

2. Fodstad $\emptyset$. Radiumhospitalet fyller 75 år. Tidsskr Nor Lægeforen 2007; 127: 1800-1.

3. Stortinget. Møte mandag den 9 . juni 2008 kl. 12 www.stortinget.no/no/Saker-og-publikasjoner/ Publikasjoner/Referater/Stortinget/2007-2008/ 080609/2/ (29.6.2010).

4. Oslo universitetssykehus HF fra 1.1.2009. Rikshospitalet (publisert 13.11.2008). www.rikshospitalet. no/ikbViewer/page/no/pages/hygiene/aktuelt/ artikkel?p doc $=432667$ (29.6.2010)

5. Spørsmål nr. 437 til skriftlig besvarelse. Brev til Stortinget 19.1.2010. Helse- og omsorgsdepartementet. www.regjeringen.no/nn/dep/hod/dok/ andre/brev/brev_til_stortinget/2010-2/Sporsmalnr-437-til-skriftlig-besvarelse- html?id=591416 (29.6.2010)

6. Haugan B. Slåss for sykehusnavn. VG 4.2.2010: 28-9.

7. Stortinget. Møte torsdag den 4. februar 2010 kl. 10 www.stortinget.no/no/Saker-og-publikasjoner/ Publikasjoner/Referater/Stortinget/2009-2010/ 100204/4/ (29.6.2010).

8. Stortinget. Møte mandag den 19. april 2010 kl. 12 www.stortinget.no/no/Saker-og-publikasjoner/ Publikasjoner/Referater/Stortinget/2009-2010/ 100419/7/ (29.6.2010).

9. Haugan B. Freder «Radiumhospitalet». VG 23.6.2010: 34.

10. Gjersvik P. Når ulike avdelinger slås sammen til én stor. Tidsskr Nor Legeforen 2009; 129: 2667.

11. Haug C. Fratatt identiteten. Tidsskr Nor Legeforen 2010; 130: 131

Manuskriptet ble mottatt 4.7. 2010 og godkjent 5.8. 2010. Medisinsk redaktør Raida Ødegaard. 